\title{
Feeding frequency on growth and male percentage during sexual reversion phase of Nile tilapia
}

\author{
Frequência de arraçoamento sobre o crescimento e percentagem de machos durante a \\ fase de reversão sexual da tilápia do Nilo
}

\section{MEURER, Fábio ${ }^{1}$ *; BOMBARDELLI, Robie Allan² ; PAIXÃO, Patrícia Santana da ${ }^{3}$; SILVA, Lilian Carolina Rosa da ${ }^{1}$; SANTOS, Lilian Dena dos ${ }^{1}$}

\author{
${ }^{1}$ Universidade Federal do Paraná, Programa de Pós-Graduação em Aquicultura e Desenvolvimento \\ Sustentável, Palotina, Paraná, Brasil. \\ ${ }^{2}$ Universidade Estadual do Oeste do Paraná, Departamento de Engenharia de Pesca, Toledo, Paraná, Brasil. \\ ${ }^{3}$ Universidade Federal do Vale do São Francisco, Campus de Ciências Agrárias, Departamento de \\ Zootecnia, Petrolina, Pernambuco, Brasil \\ *Endereço para correspondência: fabiomeurer@ufpr.br
}

SUMMARY

The sex reversal is one of the most important stages for the commercial breeding of Nile tilapia in relation to the problems arising from early breeding of this species in cultivation tanks. The objective was to determine the effect of feeding frequency on growth and sex ratio of Nile tilapia (Oreochromis niloticus) during the sex reversal phase. Five hundred Nile tilapia fry were used and stocked in twenty-five plastic aquaria (36L) in a completely randomized design with five treatments and five replicates. The treatments were: one feeding (10h), two feeding $(09 \mathrm{~h}$ and $17 \mathrm{~h})$, three feeding $(09 \mathrm{~h} ; 13 \mathrm{~h}$ and $17 \mathrm{~h}$ ), four feeding $(07 \mathrm{~h} ; 10 \mathrm{~h} ; 13 \mathrm{~h}$ and $17 \mathrm{~h})$, and five feeding $(07 \mathrm{~h} ; 09 \mathrm{~h} ; 11 \mathrm{~h} ; 15 \mathrm{~h}$ and $17 \mathrm{~h})$. The feeding frequency affected sex ratio of male fingerlings, where the treatments with four and five feedings provided similar values, but higher $(\mathrm{P}<0.01)$ than other treatments. It is recommended feeding frequency at least four times a day to provide lots with suitable index of sex reversal for cultivation.

Keywords: feeding management, fish nutrition, tilapia production.

\section{RESUMO}

A reversão sexual é uma das fases mais importantes para a criação comercial da tilápia do Nilo em função dos problemas advindos com a reprodução precoce dessa espécie em tanques de cultivo. Objetivou-se determinar o efeito da frequência de arraçoamento sobre o crescimento e a percentagem sexual da tilápia do Nilo (Oreochromis niloticus) durante a fase de reversão sexual. Quinhentas pós-larvas de tilápia do Nilo foram utilizadas e estocadas em vinte e cinco aquários plásticos (36L) em um delineamento experimental totalmente casualizado com cinco tratamentos e cinco repetições. Os tratamentos foram: uma alimentação (10h), duas alimentações (09h e 17h), três alimentações (09h; 13h e 17h), quatro alimentações $(07 \mathrm{~h} ; 10 \mathrm{~h} ; 13 \mathrm{~h}$ e $17 \mathrm{~h})$ e cinco alimentações (07h; 09h; 11h; 15h e 17h). A frequência de arraçoamento influencia a percentagem de machos, na qual os tratamentos com quatro e cinco arraçoamento proporcionam valores semelhantes entre si, porém superiores $(\mathrm{P}<0,01)$ aos demais tratamentos. Recomendam-se pelo menos quatro alimentações diárias para proporcionar lotes de alevinos de tilápia do Nilo com índice de reversão sexual adequado para a criação.

Palavras-chave: manejo alimentar, nutrição de peixes, produção de tilápia. 


\section{INTRODUCTION}

Aquaculture has been shown as one of the fastest growing activities in animal production, where freshwater fish represents the bulk of aquaculture production. The tilapia rearing follows the same trend worldwide (WINGKEONG, 2002) and in Brazil it is the main fish species (ALVES FILHO et al., 2011; MEURER et al., 2009).

Although the process of tilapia sex determination is under genetic control (DELVIN \& NAGAHAMA, 2002) sex differentiation may be influenced by environmental conditions (BOMBARDELLI et al., 2004a). This influence may be related to physical-chemical water (ORLANDO \& GUILLETTE JUNIOR, 2007; ROUGEOT et al., 2008) or the controlled administration of steroid hormones (HURLEY et al., 2004; BOMBARDELLI \& HAYASHI, 2005a; BOMBARDELLI \& HAYASHI 2005b), where the most common practice is the androgen incorporation (30 to $60 \mathrm{mg}$ of $17 \mathrm{a}-\mathrm{methyltestosterone} / \mathrm{kg}$ ) in feed, during the initial phase of the nursery (ElSAYED, 2006).

The sex reversal is one of the most important phases in rational cultivation of Nile tilapia (MEURER et al., 2008). If this management is not performed well, grow-out phase may be severely impaired due to problems related to overcrowding, caused by excessive reproductive activity of animals after reaching sexual maturity (BOMBARDELLI et al., 2004b; MEURER et al., 2005).

Thus, feeding management is important for the expression of the productive potential of fish rearing. According to Wang et al. (2007), feeding frequency is an important in feed intake, growth and pollution generated by fish. The rate at which the feed is intake and the efficiency with which it is used are primary factors in growth parameters determination (RICHE et al., 2004) and masculinization rates (SANCHES \& HAYASHI, 2001). The feeding frequency can affect performance (HAYASHI et al., 2004), survival (CANTON et al., 2007), body composition (ZHOU et al., 2003) and water quality (ZAKES et al., 2006).

The food frequency can also influence the sex reversal results, whereas methyltestosterone is rapidly metabolized and excreted (RICHARD et al., 1999) and therefore the adequacy of the number of daily feedings promote constant supply and adequate amounts of masculinizing hormone ensuring the success of this process.

The objective of this experiment was to evaluate the effects of different feeding frequencies through different numbers of daily feeding on the effectiveness of sex reversal, weight gain, survival and final length of Nile tilapia during sex reversal.

\section{MATERIAL AND METHODS}

This experiment was conducted during 30 days in the Aquaculture Laboratory of the Animal Science Department on the Experimental Farm Campus of Universidade Federal do Vale do São Francisco in Petrolina, Pernambuco State. Five hundred Nile tilapia (Oreochromis niloticus) fry two days old with an approximate mean body weight of $8.97 \pm 2.15 \mathrm{mg}$ and $0.92 \pm$ $0.05 \mathrm{~cm}$ were used. These fish were distributed in 25 plastic tanks with a capacity of $36 \mathrm{~L}$, in a completely randomized design with five treatments and five replicates. 
The treatments were different numbers of daily feeding, corresponding to one $(10 \mathrm{~h})$, two $(09 \mathrm{~h}$ and $17 \mathrm{~h})$, three $(09 \mathrm{~h}$, $13 \mathrm{~h}$ and $17 \mathrm{~h})$, four $(07 \mathrm{~h} ; 10 \mathrm{~h} ; 13 \mathrm{~h}$ and $17 \mathrm{~h})$ and five $(07 \mathrm{~h} ; 09 \mathrm{~h} ; 11 \mathrm{~h} ; 15 \mathrm{~h}$ and 17h) daily. Each experimental unit corresponded to a $36 \mathrm{~L}$ plastic tank containing 20 fry.

The aquarium water was constantly aerated and siphoned twice a day to remove feces and detritus from the bottom, during morning $(07 \mathrm{~h})$ and afternoon (17h30), with $40 \%$ of water exchange each siphoning. During the experiment last week was performed to siphon extra at $12 \mathrm{~h}$. The water temperature was measured daily at morning and afternoon, and other physicochemical parameters as $\mathrm{pH}$, dissolved oxygen and electrical conductivity of water were measured weekly in the morning, always before siphoning, using electronic equipment.

The powder diet (Table 1 and 2) was formulated to contain $38.6 \%$ digestible protein and $3.800 \mathrm{kcal} / \mathrm{kg}$ digestible energy (HAYASHI et al., 2002) and added 60mg of 17- $\alpha$ methyltestosterone/kg feed (MAINARDES-PINTO et al., 2000; BARRY et al., 2007).

For the preparation of the diets, the ingredients were ground in hammer mill, using a sieve of $0.5 \mathrm{~mm}$. Due to the high concentration of fat in fish meal and poultry by-products meal prior to grinding were sieved manually by a grid of $0.5 \mathrm{~mm}$ and then the retained fraction was ground and then mixed with the previous fraction. After mixing the feeds, was added masculinizing hormone (17- $\alpha$-methyltestosterone).

Based on initial weight, was established a feeding percentage of $50 \%$ daily, which was increased weekly, according to the growth of fish.

After the trial period, fingerlings were numbed by immersion in cold water $\left( \pm 2^{0} \mathrm{C}\right)$, counted, weighed and measured individually to evaluate the final mean weight, length, survival, specific growth rate (([ln final weight - $\ln$ initial weight] $x$ 100) / day) and daily growth rate (([final weight - initial weight] x 100) / day). After weighting, the whole fish were preserved in $10 \%$ formalin solution for the assessment of sex ratio, according to methodology described by Popma \& Green (1990).

Results related to the physical-chemical of water aquariums, sex ratio parameters, performance and survival, were subjected to analysis of variance to a $5 \%$ level of probability. In the case of evidence of significant difference, was used the Tukey test, the computer program SAEG (UFV, 1997).

Table 1. Percentile composition of experimental rations with differents soybean meal levels (as fed basis)

\begin{tabular}{lc}
\hline Ingredients & $\begin{array}{c}\text { Percentage } \\
(\%)\end{array}$ \\
\hline Soybean meal & 16,00 \\
Corn & 11,71 \\
Poultry meal & 56,80 \\
Fish meal & 5,00 \\
Soybean oil & 8,24 \\
Limestone & 0,32 \\
Dicalcium phosphate & 0,41 \\
Mineral and vitamin & 1,00 \\
supplement ${ }^{1}$ & 0,50 \\
Salt & 0,02 \\
BHT &
\end{tabular}

${ }^{1}$ Warranty levels for kilogram of product: Vit. A,1.200.000UI; Vit. D3, 200.000UI; Vit. E, $12.000 \mathrm{mg}$; Vit. K3, 2.400mg; Vit. B1, 4.800mg; Vit. B2, 4.800mg; Vit. B6, 4.000mg; Vit. B12, $4.800 \mathrm{mg}$; folic acid, $1.200 \mathrm{mg}$; Calcium Pantotenate, 12.000mg; Vit. C, 48.000mg; Biotin, 48mg; Cholin, 65.000mg; Niacin, 24.000mg; Fe, $10.000 \mathrm{mg} ; \mathrm{Cu}, 6.000 \mathrm{mg} ; \mathrm{Mn}, 4.000 \mathrm{mg} ; \mathrm{Zn}$, $6.000 \mathrm{mg}$; I, 20mg; Co, 2mg; Se, 20mg. 
Table 2. Chemical composition of experimental rations with differents levels of soybean meal (as fed basis) ${ }^{1}$

\begin{tabular}{|c|c|}
\hline Component & Value \\
\hline Dry matter $(\%)^{1,2,3}$ & 93,23 \\
\hline Digestible energy $(\mathrm{kcal} / \mathrm{kg})^{2,3}$ & 3800,00 \\
\hline Digestible protein $(\%)^{2,3}$ & 38,60 \\
\hline Crude protein $(\%)^{1,2,3}$ & 43,77 \\
\hline $\operatorname{Starch}(\%)^{3}$ & 7,69 \\
\hline Fat $(\%)^{1,2,3}$ & 19,08 \\
\hline Crude fiber $(\%)^{3}$ & 1,01 \\
\hline methionine + cystine $(\%)^{3}$ & 1,77 \\
\hline Linoleic acid $^{3}$ & 6,88 \\
\hline Lysine $(\%)^{3}$ & 2,05 \\
\hline Calcium $(\%)^{3}$ & 1,62 \\
\hline Phosphorus $(\%)^{3}$ & 0,98 \\
\hline
\end{tabular}

${ }^{\mathrm{T}}$ According Boscolo et al. (2002); ${ }^{2}$ According Meurer et al. (2003); ${ }^{3}$ According Rostagno et al. (2000).

\section{RESULTS AND DISCUSSION}

The mean values of water physicalchemical parameters measured in the aquarium during the experimental period are presented in Table 3. No difference $(\mathrm{P}>0.05)$ of water physicalchemical parameters between experimental units were observed. The values of physico-chemical parameters of water measured during the experimental period remained within the recommended range for Nile tilapia (El-SAYED, 2006).

In Figure 1 are presented mean values of final weight presented by the Nile tilapia after the period of sexual reversion subject to variation in feed frequency. The feed frequency significantly affected this parameter, the lowest weight was with one daily feeding $(\mathrm{P}<0.01)$.

Data on growth parameters and survival of Nile tilapia treated different feeding frequency during the sex reversal are presented in Table 4. The mean of the final length, specific growth rate and daily growth of Nile tilapia during the sexual reversion were influenced by different feeding frequency $(\mathrm{P}<0.01)$, where one daily feeding provided a lower performance compared to other treatments. The Nile tilapia survival during the sex reversal was not affected $(\mathrm{P}>0.05)$ by food frequency.

Table 3. Water physical-chemical parameters of plastic tanks of Nile tilapia fry subjected to variation in feeding frequency

\begin{tabular}{lccccc}
\hline $\begin{array}{l}\text { Feeding } \\
\text { frequency }\end{array}$ & $\begin{array}{c}\text { Morning } \\
\text { temperature } \\
\left({ }^{\circ} \mathrm{C}\right)\end{array}$ & $\begin{array}{c}\text { Afternoon } \\
\text { temperature } \\
\left({ }^{\circ} \mathrm{C}\right)\end{array}$ & $\begin{array}{c}\text { Dissolved } \\
\text { oxigen } \\
(\mathrm{mg} / \mathrm{L})\end{array}$ & $\mathrm{pH}$ & $\begin{array}{c}\text { Eletrical } \\
\text { conductivity } \\
(\mathrm{mS} / \mathrm{cm})\end{array}$ \\
\hline 1 & 28.3 & 29.4 & 6.61 & 7.57 & 91.20 \\
2 & 28.3 & 29.4 & 6.46 & 7.52 & 93.20 \\
3 & 28.2 & 29.4 & 6.52 & 7.50 & 92.52 \\
4 & 28.3 & 29.3 & 6.52 & 7.51 & 92.44 \\
5 & 28.2 & 29.4 & 6.59 & 7.51 & 91.60 \\
$\mathrm{CV}^{1}$ & 3.42 & 3.63 & 2.94 & 1.93 & 4.31 \\
\hline
\end{tabular}

${ }^{\mathrm{T}}$ Coefficient of variation. 


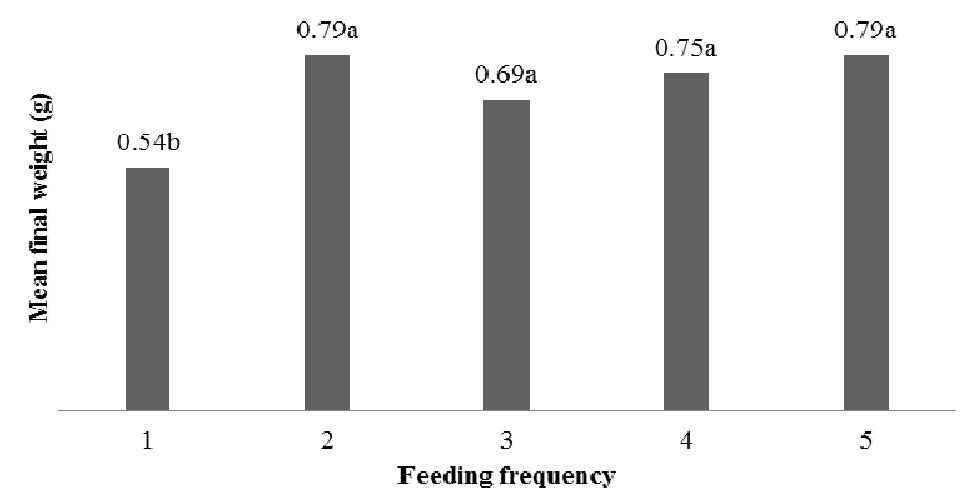

Figure 1. Final weight average of Nile tilapia fry subjected to variation in feeding frequency

Table 4. Performance parameters of Nile tilapia fry subjected to variation in feeding frequency

\begin{tabular}{lcccc}
\hline $\begin{array}{l}\text { Feeding } \\
\text { frequency }\end{array}$ & $\begin{array}{c}\text { Mean final lenght } \\
(\mathrm{cm})\end{array}$ & $\begin{array}{c}\text { Specific Growth } \\
\text { Rate }\end{array}$ & $\begin{array}{c}\text { Daily Growth } \\
\text { Rate }\end{array}$ & $\begin{array}{c}\text { Survival } \\
(\%)\end{array}$ \\
\hline 1 & $3.23^{\mathrm{b}}$ & $14.67^{\mathrm{b}}$ & $1.90^{\mathrm{b}}$ & $91.00^{\mathrm{a}}$ \\
2 & $3.63^{\mathrm{a}}$ & $16.05^{\mathrm{a}}$ & $2.81^{\mathrm{a}}$ & $92.00^{\mathrm{a}}$ \\
3 & $3.47^{\mathrm{a}}$ & $15.59^{\mathrm{a}}$ & $2.46^{\mathrm{a}}$ & $87.00^{\mathrm{a}}$ \\
4 & $3.52^{\mathrm{a}}$ & $15.89^{\mathrm{a}}$ & $2.67^{\mathrm{a}}$ & $88.00^{\mathrm{a}}$ \\
5 & $3.64^{\mathrm{a}}$ & $16.05^{\mathrm{a}}$ & $2.80^{\mathrm{a}}$ & $82.00^{\mathrm{a}}$ \\
\hline $\mathrm{CV}^{1}$ & 3.55 & 2.30 & 9.42 & 12.55 \\
\hline
\end{tabular}

Means followed by different letters in the same column different $(\mathrm{P}<0.05)$ by the Tukey's test. ${ }^{1}$ Coefficient of variation.

With regard to the influence of variation of feed frequency on productive performance, differences between treatments were observed where one daily feeding provided a lower performance compared to other treatments. The results found in the present study is not in accordance with the results reported by Sanchez \& Hayashi (2001), which showed by Tukey's test that two feeds provided the lowest performance, while the other treatments $(3 ; 4 ; 5$ and 6 feeding frequency) presented performance similar, although when those authors used the regression method, concluded that the best performances were achieved with four or five daily feeding frequency. The results of present study also disagrees with the showed by
Hayashi et al. (2004) for fingerlings of yellow tail lambari (Astyanax bimaculatus) and Zhou et al. (2003) for juveniles of Carassius auratus.

The difference between productive performance results found in this experiment compared with ones found by Sanches \& Hayashi (2001) can be explained due to the fact that the environmental conditions were different. In the present experiment were used a closed system, just like a concrete tank or chute, where fry had access to leftover feed until they were siphoned. In the experiment of Sanchez \& Hayashi (2001) the fry were stocked in hapas, where there was not the same opportunity for access to scraps of feed, but there were natural food. However, 
even this way, the difference between the results of both experiments were small, ranging from two to three feedings

In Figure 2 are presented mean values of sex ratio displayed by the Nile tilapia after the period of sexual reversion subject to variation in feed frequency. The feed frequency significantly affected the sex ratio of male juveniles, which four and five feedings have provided similar values, but higher $(\mathrm{P}<0.01)$ than other treatments.

It appears that the benefit of a higher feeding frequency for Nile tilapia during sex reversal is precisely the optimization of phenotypic male percetage. Treatments with four or more daily feedings promoted higher masculinization rates (Figure 2). Conversely, it was found that treatments with four or more feedings reduce the occurrence of intersex individuals (Figure 2). Thus, considering that intersex individuals may occur due to the inefficiency of hormone treatment (CARVALHO \& FORESTI, 1996), the results corroborate the data of masculinization, where treatments become more efficient as it increases the number of daily feeds, reducing therefore, the contents of an intersexual. A similar result as the inverse relationship between the occurrence of male and intersex individuals was verified by Bombardelli \& Hayashi (2005a).

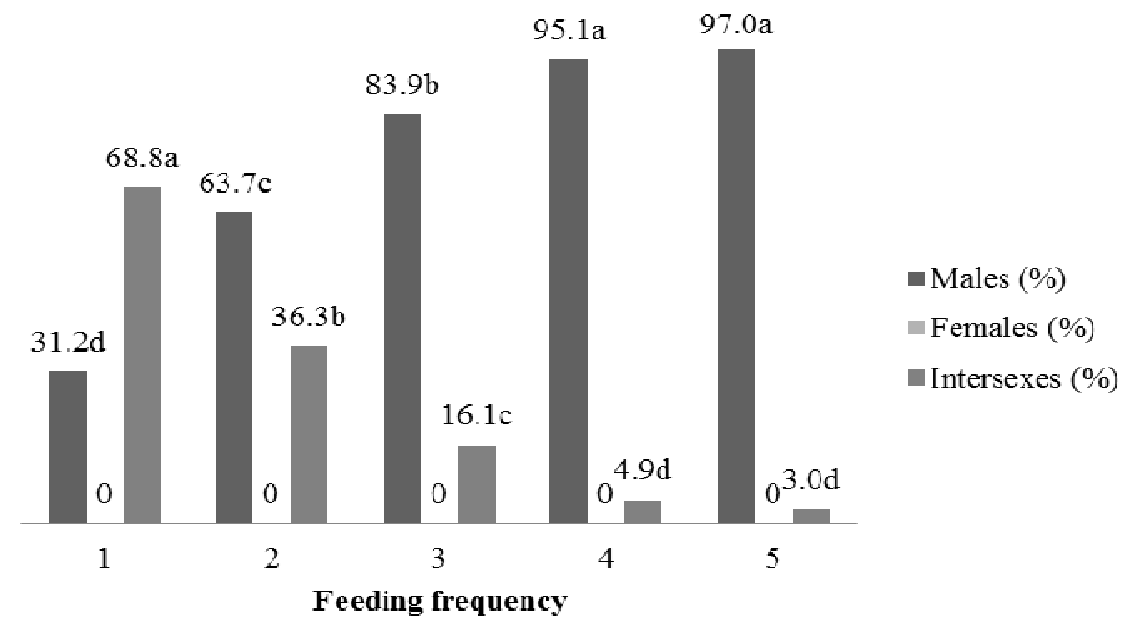

Figure 2. Mean values of the percentage of males, females and intersexes of Nile tilapia fry subjected to variation in feeding frequency

Furthermore, although not verified the presence of phenotypic females in any treatment, the presence of intersex fish can not guarantee that these individuals may present reproductive activity or even loss of growth due to the diversion of metabolic energy related to these activities.

Gale et al. (1999) assert that the hierarchy that occurs in a tank setting promotes a change in feed intake that can reflect the variation of sex ratios. The effect of feeding frequency on the proportion of phenotypic males in Nile tilapia, according to Richard et al. (1999), in experiments with 17- $\alpha$-methyltestosterone radiolabeled, demonstrates that this is rapidly metabolized and excreted. Thus, maintaining a more frequent intake of 17 - 
$\alpha$-methyl-testosterone in the bloodstream of Nile tilapia fry is likely to optimize the process of masculinization.

The survival found in this study is in agreement with Sanchez \& Hayashi (2001) and Rowland et al. (2005) for silver perch (Bidyanus bidyanus). On the other hand, disagree with the results found by Hayashi et al. (2004), that studying feeding frequency for lambari found a linear decrease of survival with increasing of feeding frequency. With regards to the influence of feeding frequency on sex ratio, four and five daily feedings provided higher values of males compared to other treatments, which corroborate the effect reported by Mainardes-Pinto et al. (2000) and Green $\&$ Teichert-Coddington (1994) for Nile tilapia using four daily feeding.

Regarding survival, Sanches \& Hayashi (2001) report that high survival of tilapia may be related to availability of natural food. However, it appears that only one daily feeding with a wellbalanced ration, even without the availability of natural food is sufficient to maintain adequate survival of Nile tilapia lots during sex reversal.

The feeding frequency is an element of management that involves labor, thus increasing this frequency causes an increase in spending on activity, influencing the final profit of the activity (HAYASHI et al., 2004). From the standpoint of growth and survival, keeping only two daily feedings already provides a good performance without affecting survival. This may be related to stomach capacity of Nile tilapia, which stores enough food to provide good growth from two daily feedings.

Thus one could infer the possibility of only two daily feeding for lots of fry of Nile tilapia were not under the process of sex reversal, as the case of batch production for breeding or production batches monosex through management manual sexing. However in this case would require the evaluation of body composition to see if there would be no excess fat deposition, due to a large amount of nutrients in just two feedings. To breeding specifically, assess whether two daily feeding represents an appropriate feeding regime for the animal to obtain nutrients in sufficient quantity and quality to reach sexual maturity/puberty within acceptable production standards (GUNASEKERA et al., 1995).

Increased feeding frequency should provide a constant supply of masculinizing hormone in the bloodstream. Thus, the tissue differentiation affect the ovary development in the female germpreventing reproduction during farming. The increased frequency of food is related to increased cost of labor or the implementation of automatic feeders. However, it is a cost that must be considered as producers of fingerlings with a history of onset of spawning in the tanks of their customers usually end up becoming discredited in the market and thus endanger your business.Feeding frequency has significant effect on productive performance and sex reversal of Nile tilapia. It is recommended feeding frequency at least four times a day to provide lots with suitable index of sex reversal for cultivation.

\section{ACKNOWLEDGMENTS}

The authors thank Conselho Nacional de Desenvolvimento Científico e Tecnológico $(\mathrm{CNPq})$ for the scholarships and the 3rd Regional Agency of CODEVASF at Petrolina, particularly for the support of Rozzano Antonio Cavalcante Reis de Figueiredo and Marcelo Barbalho, fishing engineers of the Bebedouro Fish Culture Station who supplied Nile tilapia larvae. 
Rev. Bras. Saúde Prod. Anim., Salvador, v.13, n.4, p.1133-1142 out./dez., 2012 http://www.rbspa.ufba.br ISSN 15199940

\section{REFERENCES}

ALVES FILHO, F.M.; SANTOS, L.D.; SILVA, L.C.R.; BOMBARDELLI, R.A.; MEURER, F. Alga marrom (Ascophyllum nodosum) para alevinos de tilápia do Nilo. Revista Brasileira de Saúde e Produção Animal [Online], v.12, n.4, p.1095-1102, 2011.

BARRY, T.P.; MARWAH, A.; MARWAH, P. Stability of $17 \alpha-$ methyltestosterone in fish feed.

Aquaculture, v.271, n.1-4, p.523-529, 2007.

BOMBARDELLI, R.A.; HAYASHI, C. Feminilização de larvas de tilápia do Nilo (Oreochromis niloticus L.) a partir de banhos de imersão com valerato-deestradiol. Revista Brasileira de

Zootecnia, v.34, n.2, p.357-364, 2005 b.

BOMBARDELLI, R.A.; HAYASHI, C. Masculinização de larvas de tilápia do Nilo (Oreochromis niloticus L.) a partir de banhos de imersão com 17aMetiltestosterona. Revista Brasileira de Zootecnia, v.34, n.2, p.365-372, 2005a.

BOMBARDELLI, R.A.; HAYASHI, C.; MEURER, F. Aplicação de métodos diretos e indiretos para a produção de populações monossexuais na tilapicultura. Arquivo de Ciências Veterinárias e Zoologia UNIPAR, v.7, n.1, p.57-68, 2004a.

BOMBARDELLI, R.A.; HAYASHI, C.; MEURER, F.; FORNARI, D.C.

Masculinização de larvas de tilápia do Nilo (Oreochromis niloticus) por banhos de imersão e o andrógeno dissolvido em solução de dimetilsulfóxido (DMSO). Acta Scientiarum Animal Science, v.26, n.2, p.209-215, 2004b.
BOSCOLO, W.R.; HAYASHI, C.; MEURER, F. Digestibilidade aparente da energia e nutrientes de alimentos convencionais e alternativos para o tilápia do Nilo (Oreochromis niloticus). Revista Brasileira de Zootecnia, v.31, n.2, p.539-545, 2002.

CANTON, R.; WEINGARTNER, M; FRACALOSSI, D.M., ZANIBONI FILHO, F. Influência da freqüência alimentar no desempenho de juvenis de jundiá. Revista Brasileira de

Zootecnia, v.36, n.4, p.749-753, 2007.

CARVALHO, E.D.; FORESTI, F. Reversão de sexo em tilápia do Nilo, Oreochromis niloticus Trewavas, 1983, induzida por $17 \alpha$ metiltestosterona: proporção de sexo e histologia das gônadas. Revista Brasileira de Biologia, v.56, n.2, p.249-262, 1996.

DEVLIN, R.; NAGAHAMA, Y. Sex determination and sex differentiation in fish: an overview of genetic, physiological, and environmental influences. Aquaculture, v.208, n.3-4, p.191-364, 2002.

El-SAYED, A.M. Tilapia culture. Oxford: CABI Publishing, 2006. 277p.

GALE, W.L.; FITZPATRICK, M.S.; LUCERO, M.; CONTRERASSANCHES, W.M., SCHRECK, C.B. Masculinization of Nile tilapia Oreochromis niloticus by immersion in androgens. Aquaculture, v.178, n.3-4, p.349-357, 1999.

GREEN, B.W.; TEICHERTCODDINGTON, D.R. Growth of control and androgen-treated Nile tilapia, Oreochromis niloticus (L.), during treatment, nursery and grow-out phases in tropical fish ponds. Aquaculture and Fisheries Management, v.25, n.6, p.613-621, 1994. 
Rev. Bras. Saúde Prod. Anim., Salvador, v.13, n.4, p.1133-1142 out./dez., 2012 http://www.rbspa.ufba.br ISSN 15199940

GUNASEKERA, R.M.; SHIM, K.F.; LAM, T.J. Effects of dietary protein level on puberty, oocyte growth and egg chemical composition in the tilapia, Oreochromis niloticus (L.).

Aquaculture, v.134, n.1-2, p.169-183, 1995.

HAYASHI, C.; BOSCOLO, W.R.; SOARES, C.M.; MEURER, F. Exigência de proteína digestível para larvas de tilápia do Nilo no período de reversão sexual. Revista Brasileira de Zootecnia, v.2, n.2S, p.823-828, 2002.

HAYASHI, C.; MEURER, F.; BOSCOLO, W.R.; LACERDA, C.H.F.; KAVATA, L.C.B. Freqüiência de arraçoamento para alevinos de lambari do rabo-amarelo (Astyanax bimaculatus). Revista Brasileira de Zootecnia, v.33, n.4, p.21-26, 2004.

HURLEY, M.A.; MATTHIESSEN, P.; PICKERING, A.D. A model for environmental sex reversal in fish.

Journal of Theoretical Biology, v.227, n.2, p.159-165, 2004.

MAINARDES-PINTO, C.S.R.; FENERICH-VERANI, N.; CAMPOS, B.E.S.; SILVA, A.L. Masculinização da tilápia do Nilo, Oreochromis niloticus, utilizando diferentes rações e diferentes doses de 17 a-Metiltestosterona.

Revista Brasileira de Zootecnia, v.29, n.3, p.654-659, 2000.

MEURER, F.; COSTA, M.M.; BARROS, D.A.D.; OLIVEIRA, S.T.L.; PAIXÃO, P.S. Brown propolis extract in feed as a growth promoter of Nile tilapia (Oreochromis niloticus, Linnaeus 1758) fingerlings. Aquaculture

Research, v.40, n.5, p.603-608, 2009.

MEURER, F.; HAYASHI, C.; BOSCOLO, W.R. Digestibilidade aparente de alguns alimentos protéicos pela tilápia do Nilo (Oreochromis niloticus, L.). Revista Brasileira de Zootecnia, v.32, n.8, p.1801-1809, 2003.

MEURER, F.; HAYASHI, C; BARBERO, L.M.; SANTOS, L.D.; BOMBARDELLI, R.A.; COLPINI, L.M.S. Farelo de soja na alimentação de tilápias-do-nilo durante o período de reversão sexual. Revista Brasileira de Zootecnia, v.37, n.5, p.791-794, 2008.

MEURER, F.; HAYASHI, C; BOSCOLO, W.R.; SCHAMBER, C.R.; BOMBARDELLI, R.A. Fontes protéicas suplementadas com aminoácidos e minerais para a tilápia do Nilo durante a reversão sexual. Revista Brasileira de Zootecnia, v.34, n.1, p.16, 2005.

ORLANDO, E.F.; GUILLETTE JUNIOR, L.J. Sexual dimorphic responses in wildlife exposed to endocrine disrupting chemicals.

Environmental Research, v.104, n.1, p.163-173, 2007.

POPMA, T.J.; GREEN, B.W .

Aquacultural production manual: sex reversal of tilapia in earthen ponds.

Research and Development series, v.35, p.1-5, 1990.

RICHARD, J.; DABROWSKI, K.; GARCIA-ABIADO, M.A.; OTTOBRE, J. Uptake and depletion of plasma 17amethyltestosterone during induction of masculinization in muskellunge, Esox masquinongy: Effect on plasma steroids and sex reversal. Steroids, v.64, n.8, p.518-525, 1999.

RICHE, M., HALEY, D.I.; OETKER, M.; GARBRECHT, S.; GARLING, D.L. Effect of feeding frequency on gastric evacuation and the return of appetite in tilapia Oreochromis niloticus 
(L.). Aquaculture, v.234, n..1-4, p.657-673, 2004.

ROUGEOT, C.; PRIGNON, C.;

KENGNE, C. V.; MELARD, C. Effect of high temperature during embryogenesis on the sex differentiation process in the Nile tilapia, Oreochromis niloticus.

Aquaculture, v.276, n.1-4, p.205-208, 2008.

ROWLANDA, S.J.; ALLAN, G.L.; MIFSUD, C.; NIXON, M.; BOYD, P.; GLENDENNING, D. Development of a feeding strategy for silver perch,

Bidyanus bidyanus (Mitchell), based on restricted rations. Aquaculture

Research, v.36, n.14, p.1429-1441, 2005.

SANCHES, L.E.F.; HAYASHI, C. Effect of feeding frequency on Nile tilapia, Oreochromis niloticus (L.) fries performance during sex reversal in hapas. Acta Scientiarum, v.23, p.871876, 2001.

UNIVERSIDADE FEDERAL DE VIÇOSA - UFV. SAEG Sistema para análises estatísticas e genéticas.

Versão 7.1. Viçosa, MG, 1997. 150p.

(Manual do usuário).
WANG, Y.; KONG, L.; LI, K.;

BUREAU, D.P. Effects of feeding frequency and ration level on growth, feed utilization and nitrogen waste output of cuneate drum (Nibea miichthioides) reared in net pens. Aquaculture, v.271, n.1-4, p.350-356, 2007.

WING-KEONG, N. Potencial of palm oil utilization in aquaculture feeds. Asia Pacific Journal of Clinical Nutrition, v.11, n.7, p.473-476, 2002.

ZAKES, Z.; DEMSKA-ZAKES, K.; JAROCKI, P.; STAWECKI, K. The effect of feeding on oxygen consumption and ammonia excretion of juvenile tench Tinca tinca (L.) reared in a water recirculating system.

Aquaculture International, v.14, n.12, p.127-140, 2006.

ZHOU, Z.; CUI, Y.; XIE, S.; ZHU, W.; LEI, W.; XUE, M.; YANG, Y. Effect of feeding frequency on growth, feed utilization, and size variation of juvenile gibel carp (Carassius auratus gibelio).

Journal of Applied Ichthyology, v.19, n.4, p.244-249, 2003.

Data de recebimento: 18/06/2012

Data de aprovação: 05/12/2012 